УДК 343.28/.29

DOI https://doi.org/10.32849/2663-5313/2020.2.47

\title{
Максим Глоба,
}

здобувач кафедри кримінального права № 1

Національного юридичного університету імені Ярослава Мудрого

\section{КРИМІНАЛЬНО-ПРАВОВІ НАСЛІДКИ УКЛАДЕННЯ УГОДИ ПРО ВИЗНАННЯ ВИНУВАТОСТІ У США ТА ВЕЛИКОБРИТАНІї}

У статті розглядається та аналізується зарубіжний досвід правового регулювання кримінально-правових наслідків у разі укладення угоди про визнання винуватості. На прикладі країн США та Великобританії показано особливості призначення покарання у разі визнання винуватості в англосаксонській системі права. Вирішення кримінально-правового конфлікту шляхом укладення угоди про визнання винуватості є досить поширеним у США та Великобританії. Встановлено, що американська модель погоджувальних прочедур стала ідеологічною базою для формування та поширення даного методу у кримінальному судочинстві в інших країнах. У кримінальному прочесі США передбачається можливість укладення різних видів угод. Угода про визнання винуватості («plea bargain») полягає у відмові обвинуваченого від судового розгляду його справи в обмін на пом'якшення кримінальної відповідальності. Ї̈ видами є угода щодо покарання та угода щодо обвинувачення. У разі укладення угоди щодо покарання («Sentence Bargaining») прокурор пропонує пом'якшити покарання в обмін на визнання винуватості підозрюваним, а в разі укладення угоди шодо обвинувачення («Сharge bargaining») прокурор погоджується зменшити обсяг обвинувачення шляхом відмови від деяких звинувачень або перекваліфікачії вчиненого на менш тяжкий злочин чи проступок в обмін на визнання винуватості підозрюваним. Іншим видом угоди у кримінальному прочесі США є угода про співпрацю. Ïі зміст полягає у сприянні підозрюваним/обвинуваченим розслідуванню і судовому переслідуванню злочинної діяльності інших осіб, які не є обвинуваченими, в обмін на обов'язкове пом'якшення кримінальної відповідальності за його власну протиправну поведінку. За законодавством Великобританії, якщо обвинувачений визнає свою винуватість за певними пунктами обвинувального акта, за іншими пунктами обвинувачення не здійснюється, а відповідальність пом'якшується. Максимальний рівень пом'якшення покарання у разі визнання винуватості становить третину від максимального строку покарання, передбаченого за вчинений злочин, а індивідуальний ступень пом'якшення залежить від стадії розгляду справи у суді, на якій була зроблена така заява.

Ключові слова: угода, визнання винуватості, призначення покарання, кримінально-правовий конфлікт, узгодження покарання.

Постановка проблеми. Реформа кримінального процесуального законодавства, яка відбувалась у зв'язку 3 прийняттям у 2012 р. нового Кримінального процесуального кодексу України (далі - КПК), торкнулась і сфери вітчизняного кримінального права, яке поповнилось новими нормами, що закріплюють можливість призначення покарання на підставі угоди між прокурором і підозрюваним/обвинуваченим про визнання винуватості (далі - угода про визнання винуватості). Угода про визнання винуватості - це форма добровільної домовленості між обвинувачем (прокурором) і підозрюваним/обвинуваченим, за якої сторони після початку кримінального провадження або після вручення письмового повідомлення про підозру узгоджують кримінально-правові наслідки вчиненого злочину за наявності беззастережного визнання останнім своєї винуватості у цьому делікті. Якщо порядок укладення такої угоди детально регулюється у КПК (Глава 35 «Кримінальне провадження на підставі угод»), то у Кримінальному кодексі України (далі - КК) цьому питанню присвячені тільки ч. 5 ст. 65 КК та ч. 2 ст. 75 КК, які лише констатують факт наявності у суду повноважень у разі укладення такої угоди призначити узгоджене покарання або звільнити засудженого від відбування узгодженого покарання 3 випробуванням. Водночас у КК відсутні спеціальні правила призначення покарання у разі укладення такої угоди.

Аналіз останніх досліджень і публікацій із цієї теми свідчить про відсутність належної уваги з боку науковців до проблеми призначення покарання у зв'язку 3 укладенням угоди про визнання винуватості, незважаючи на те, що окремим аспектам 
інститутів призначення покарання та угоди про визнання винуватості присвячені численні наукові публікації. Загальні тенденції розвитку цих інститутів у своїх працях вивчали П. П. Андрушко, Р. Ш. Бабанли, В. М. Бурдін, М. М. Васюк, А. А. Вознюк, В. Г. Дрозд, О. О. Дудоров, С. М. Міщенко, В. В. Навроцька, Р. В. Новак, О. В. Плахотнік, Ю. А Пономаренко, В. І. Тютюгін, М. І. Хавронюк, Ю. В. Шинкарьов та багато інших. Проте в аспекті зарубіжного досвіду правової регламентації призначення покарання у разі укладення угоди про визнання винуватості ця проблема є малодослідженою.

Метою статті є аналіз правового регулювання призначення покарання у разі укладення угоди про визнання винуватості у США та Великобританії для вироблення шляхів удосконалення відповідних вітчизняних кримінально-правових норм.

Виклад основного матеріалу. Якщо для вітчизняної правової системи призначення покарання на підставі укладення угоди про визнання винуватості є новим, то у зарубіжному праві вирішення кримінально-правових конфліктів у такий спосіб використовується вже давно та є досить поширеним. Вирішення кримінальних справ на підставі угоди про визнання винуватості застосовується у багатьох країнах, зокрема в Австралії, Болгарії, Великобританії, Грузії, Естонії, Іспанії, Литві, Канаді, Нідерландах, Німеччині, Норвегії, Польщі, США, Франції, Швейцарії та багатьох інших. Англія та США одними 3 перших почали використовувати даний спосіб вирішення кримінально-правового конфлікту. Вважається, що саме американська модель погоджувальних процедур стала ідеологічною базою для формування та поширення даного методу у кримінальному судочинстві в інших країнах.

У кримінальному процесі США передбачається можливість укладення двох видів угод: щодо визнання винуватості та співробітництво зі слідством. Передумови, підстави та порядок їх укладення закріплюються у Федеральних правилах кримінального судочинства (правило 11) [1], Зводі законів США (section. 18 U.S.C. § 3553(c)) [2], Федеральних керівних принципах винесення вироків США (§ 5 K 1.1.) [3]

У США угода між прокурором та обвинуваченим має назву «plea bargain». Ї̈ї зміст полягає у тому, що обвинувачений відмовляється від свого конституційного права на розгляд справи судом з одночасним визнанням своє винуватості у вчиненому злочині в обмін на застосування менш суворої відповідальності, ніж та, яку він міг би зазнати у разі розгляду справи судом у загальному порядку.

Даний інститут $є$ органічною частиною кримінального судочинства США вже біля 200 років. Перші згадування про розгляд кримінальних справ на підставі угод про визнання винуватості у США припадають на початок XIX ст. Втім, якщо до початку XX ст. такий спосіб вирішення кримінальноправового конфлікту мав винятковий характер та становив лише $20 \%$ від усіх судових рішень, то на сучасному етапі цей метод $€$ домінуючим в американському судочинстві, а його доля зросла майже до 97 \% [4].

У правовій літературі зазначається, що право на суд присяжних було центральною частиною системи правосуддя у перші роки існування США та визнавалось невід'ємною частиною громадянських свобод американців відповідно до сьомої поправки Білю про права [5]. Саме тому процедура укладення угоди про визнання винуватості у кримінальному судочинстві не зустрічається в колоніальній Америці. Однак на початку XIX сторіччя збільшення навантаження на суд призвело до того, що судовий розгляд міг тривати від декількох хвилин або годин до декількох тижнів або місяців [6]. У зв'язку 3 цим у цей період у США з'являється тенденція щодо відходу від класичної моделі обвинувального кримінального судочинства: з'ясування усіх фактичних обставин справи, пошуку істини та доказування вини особи. Оголошення себе винним визнається достатнім для прийняття судом рішення по справі. Причинами популярності практики укладання угоди про визнання винуватості у кримінальному процесі США вважаються: досить складний, громіздкий та тривалий процес судового розгляду кримінальних справ; відсутність значної кількості адвокатів, які б могли надати кваліфіковану правову допомогу, внаслідок чого винна особа залишалася сам на сам перед караючим мечем правосуддя; прагнення винного отримати гарантоване пом'якшення відповідальності замість непередбачуваного рішення суду присяжних, який зазвичай був схильним до застосування найсуворіших заходів кримінально-правового характеру. Ці факти у поєднанні з корумпованою атмосферою американського кримінального судочинства, яка перешкоджала справедливому розгляду кримінальних справ наприкінці XIX - на початку XX ст., у правовій літературі визнаються причинами, що сприяли росту кількості кримінальних справ, що вирішувались шляхом перемовин щодо визнання винуватості, незважаючи на їх засудження апеляційними судами [7]. 
У 1946 році визнання винуватості як правовий інститут отримало своє закріплення у Федеральних правилах кримінального судочинства. Правило 11 цього нормативноправового акта детально регламентує порядок та наслідки укладання угоди про визнання винуватості у кримінальному процесі [1]. Особливістю американської погоджувальної процедури є те, що угода може бути укладена у разі вчинення будь-якого злочину, незалежно від його виду, тяжкості та наявності потерпілого. При цьому дослідження доказів у суді практично не проводиться, а визнання визнається обставиною, яка не потребує свого підтвердження конкретними фактичними обставинами по справі та є достатньою самостійною підставою для затвердження укладеної угоди судом. При цьому Федеральні правила кримінального судочинства США не гарантують обов'язкового пом'якшення покарання у разі застосування погоджувальних процедур.

У США досить поширені два види угод між правопорушником та прокурором: угода щодо покарання та угода щодо обвинувачення. Угода щодо покарання («Sentence Bargaining») полягає у тому, що прокурор пропонує пом'якшити покарання в обмін на визнання винуватості підозрюваним. У разі укладення угоди щодо обвинувачення («Charge bargaining») прокурор погоджується зменшити обсяг обвинувачення шляхом відмови від деяких звинувачень або перекваліфікації вчиненого на менш тяжкий злочин чи проступок в обмін на визнання винуватості підозрюваним [7]. Наприклад, перекваліфікувати вбивство першого ступеня (американський аналог особливо кваліфікованого складу вбивства (ч. 2 ст. 115 КК)) на вбивство третього ступеня (американський аналог основного складу вбивства (ч. 1 ст. 115 КК)) або виключити зі змісту звинувачення один чи декілька епізодів злочинної діяльності винного [8]. Так, відповідно до п. (1) ч. (с) правила 11 Федеральних правил кримінального судочинства в США, якщо обвинувачений визнає себе винуватим або побажає не оскаржувати свою вину у пред'явлених злочинах або в менш тяжких злочинах, зазначених угодою, то сторона обвинувачення може: а) не висувати нові звинувачення або відмовитися від інших пред'явлених звинувачень; б) рекомендувати суду не перешкоджати проханню обвинуваченого призначити йому певне покарання або покарання в певних межах; в) рекомендувати суду враховувати або не враховувати певне положення Федеральних правил щодо ухвалення вироків або конкретну пом'якшуючу або обтяжуючу обставину [1].
Відповідно до п. (1) ч. (c) правила 11 Федеральних правил кримінального судочинства в США суд не бере участі у процесі укладення угоди та формуванні її змісту. Сторонами угоди виступають виключно обвинувачений та державний обвинувач, які проводять конфіденційні перемовини, участь у яких бере також захисник. Що ж стосується потерпілого, то його участі у процесі укладення угоди про визнання винуватості не передбачено.

Умовами затвердження консенсуальної угоди судом є встановлення: 1) факту добровільності визнання винуватості обвинуваченим, тобто того, що оголошення себе винним не є результатом застосування сили, погроз або певних обіцянок (крім обіцянки щодо укладення угоди); 2) наявності фактичної підстави для укладення угоди, тобто встановлення дійсного факту вчинення злочину.

У разі затвердження угоди повний судовий розгляд за участю суду присяжних не здійснюється. Суд зазвичай визнає доведеними саме ті звинувачення та обмежується тими доказами, які визнали доцільним заявити сторони угоди. У такій ситуації обвинувальний вирок фактично виконує роль акта, який надає силу і звертає до виконання рішення, закріплене сторонами угоди. Водночас умови угоди є обов'язковими для iï сторін. Однак, якщо суд, розглядаючи угоду, дійте висновку, що ії зміст суперечить публічним інтересам, він може призначити більш суворе покарання, ніж те, що узгодили сторони, або відмовити у іiі затверджені та призначити розгляд справи у загальному порядку. Саме така ситуація мала місце у кримінальній справі відомого американського гангстеру Аль Капоне, який, розраховуючи на суттєве пом'якшення покарання, уклав угоду з прокурором про визнання винуватості. Проте суддя відмовив у затверджені цієї угоди та замість покарання у виді п'яти років позбавлення волі, яке було предметом домовленості між злочинцем та прокурором, призначив одинадцять років позбавлення волі [9].

Іншим видом угоди, яка може бути укладена у кримінальному процесі США, є угода про співпрацю (section. 18 U.S.C. § 3553(c)) [2]. Відмінність між угодою про співпрацю та угодою про визнання винуватості полягає у тому, що в останньому випадку допомога з боку підозрюваного (обвинуваченого) спрямована на розслідування і судове переслідування злочинної діяльності інших осіб, які не $€$ обвинуваченими, тоді як при оголошенні себе винним має місце згода на відповідальність за власну поведінку. Зміст правових наслідків угоди про співпрацю у криміналь- 
ному процесі США полягає в тому, що особа, яка визнала свою винуватість та допомагає розслідуванню іншого злочину або судовому переслідуванню особи, яка його вчинила, може розраховувати на призначення більш м'якого покарання, ніж передбачено законом за вчинений нею злочин. Така допомога органам влади визнається самостійною пом'якшуючою обставиною та виступае спеціальною підставою для обов'язкового зниження покарання. Останніми роками вирішення кримінальних справ на підставі «істотної допомоги» застосовувалось майже у чверті усіх федеральних справ [10]. Застосування більш м'якого покарання, ніж передбачено законом за вчинений злочин, для цих випадків не тільки спонсорується стороною обвинувачення, а й прямо дозволяється Керівними принципами винесення вироків (§5 K1.1.) [3].

Порядок укладення угоди про визнання винуватості у Великобританії має схожі риси з американською моделлю. У разі, якщо обвинувачений визнає свою винуватість за певними пунктами обвинувального акта, за іншими пунктами обвинувачення не здійснюється, а відповідальність пом'якшується. Відповідно до ст. 144 Закону про кримінальне правосуддя («Criminal Justice Act») 2003 р. [11] (далі - Закон) сторонами угоди про визнання винуватості виступає прокурор та особа, яка вчинила злочин. Суд і потерпілий не є сторонами даної угоди, при цьому згода останнього не визнається умовою для іï укладення. Угода про визнання винуватості може бути укладена між сторонами на будь-якій стадії розгляду справи, але до видалення суду в нарадчу кімнату. У ст. 144 Закону передбачається обов'язкове пом'якшення покарання у разі укладення угоди про визнання винуватості. Водночас положення ст. 144 не конкретизують ступеня пом'якшення відповідальності та умов, від яких воно залежить. У зв'язку з цим з метою впорядкування та уніфікації судової практики у сфері призначення покарання на підставі угод Апеляційний суд Великобританії розробив керівництво щодо винесення вироків у справах про визнання винуватості, яке вступило в силу 1 червня 2017 р. та має обов'язковий характер для магістратських судів та суду Корони [12]. Так, згідно 3 цим керівництвом максимальний рівень пом'якшення покарання у разі визнання винуватості становить третину від максимального строку покарання, передбаченого за вчинений злочин. При цьому індивідуальний ступень пом'якшення залежить від стадії розгляду справи у суді, на якій була зроблена заява. Такий диференційований підхід щодо ступеня пом'якшення покликаний стимулювати до більш раннього визнання особою своєї винуватості. Так, якщо заява була зроблена у день першого слухання на стадії попереднього розгляду справи у суді, покарання має бути обов'язково пом'якшено на одну третину. Після першого слухання максимальний рівень скорочується до однієї четвертої. 3 кожним наступним судовим засіданням на стадії попереднього судового розгляду обов'язковий ступень пом'якшення покарання зменшується з однієї четвертої до десятої, тобто скорочення знижок відбувається в міру наближення дати судового розгляду справи. При цьому, якщо клопотання щодо визнання винуватості вноситься під час судового розгляду справи, обов'язкове пом'якшення покарання може взагалі виключатися [12]. Водночас скорочення строків або розмірів покарання не допускається у разі вчинення злочину з використанням зброї або якщо результатом пом'якшення покарання може стати його обрання у розмірі, нижчому за його допустимий мінімум, а також у разі вчинення вбивства, яке карається довічним позбавленням волі [13].

\section{Висновки}

Укладення угоди про визнання винуватості є досить поширеним способом вирішення кримінально-правового конфлікту у судовій практиці США та Великобританії. Доцільність існування цього способу перевірена та підтверджена часом та правозастосовною практикою. Правове значення даного інституту в системі кримінального судочинства полягає у скороченні фінансових витрат на судочинство, скорішому відновленню прав потерпілої сторони, наданні можливості правоохоронним органам зосередити свої зусилля на найбільш складних i резонансних злочинах. Особливістю угоди про визнання винуватості за законодавством США та Великобританії є те, що вона може бути укладена у разі вчинення будь-якого злочину та на будь-якій стадії розгляду справи, проте до виходу суду у нарадчу кімнату. Сторонами угоди виступають прокурор та підозрюваний (обвинувачений), які у тому числі можуть домовлятися про вид та розмір покарання. Проте суд не зв'язаний умовами угоди, а тому, якщо її зміст суперечить публічним інтересам, він може відійти від досягнутих домовленостей та призначити інше, більш суворе, покарання, ніж було узгоджено сторонами угоди, або призначити розгляд справи у загальному порядку. На законодавчому рівні не гарантується обов'язкове пом'якшення покарання у разі укладення угоди про визнання винуватості, проте на 
практиці це є досить поширеним. Водночас інший вид угоди, а саме угода про співпрацю, змістом якої є сприяння розкриттю злочинної діяльності іншої особи або допомога у іiї встановлені чи затриманні, визнається самостійною підставою для обов'язкового пом'якшення покарання.

\section{Список використаних джерел:}

1. Federal Rules of Criminal Procedure. URL: https://www.federalrulesofcriminalprocedure.org/ title-iv/rule-11-pleas/ (дата звернення: 10.11.2019).
2. United States
Code.
URL:

https: / www.law.cornell.edu/uscode/text / 18/3553(дата звернення: 10.12.2019).

3. United States sentencing commission Guidelines Manual. URL: https://www.ussc.gov/sites/ default/files/pdf/guidelines-manual/2014/ GLMFull.pdf (дата звернення: 10.12.2019).

4. Lindsey Devers Plea and Charge Bargaining Research Summary. URL: https://www.bja.gov/ Publications/PleaBargainingResearchSummary.pdf. (дата звернення: 10.12.2019).

5. Hari Kishan Darker side of plea bargaining: The worldwide scenario with future perspectives. International Journal of Advance Research and Developmen. Volume 3, Issue 6. 2018. P. 28-37. URL: www.ijarnd.com/manuscripts/v3i6/V3I6-1147.pdf (дата звернення: 10.12.2019).

6. Emily Yoffe Innocence Is Irrelevant. The Atlantic. September 2017. URL: https://www.theatlantic.com/magazine/ archive/2017/09/innocence-is-irrelevant/534171/ (дата звернення: 18.12.2019).
7. Albert W. Alschuler Plea Bargaining and Its History. Law \& Society Review. 1979. Vol. 79. № 1. 1-44pp.URL:https://chicagounbound.uchicago.edu/ cgi $/$ viewcontent.cgi article $=2005 \&$ context $=$ journal_articles (дата звернення: 18.12.2019).

8. Йванов А. А. Правовое регулирование института сделок о признании вины в США. Becmник Нижегородского университета им. Н.И. Лобачевского. 2012. № 2 (1). С. 282-286.

9. AL Capone / New World Encyclopedia. Previous (Al-Wathiq). URL: https://www.newworldencyclopedia.org/entry/Al_Capone Photograph Al Capone in Philadelphia, $\bar{P}$ ennsylvania, where he had been arrested and charged with carrying a concealed weapon, 1929/ (дата звернення: 11.12.2019).

10. Federal Sentencing: The Basics. United States sentencing commission. Washington. 2015. URL: https://www.ussc.gov/sites/default/files/pdf/ research-and-publications/research-projects-andsurveys/miscellaneous/201510 fed-sentencingbasics.pdf (дата звернення: 11.12.2019).

11. Criminal Justice Act 2003. URL: http://www.legislation.gov.uk/ukpga/2003/44/part/ 12/chapter/1/enacted (дата звернення: 09.12.2019).

12. Reduction in Sentence for a Guilty Plea Briefing paper. Number 5974, 15 November 2017. URL: https://researchbriefings.parliament.uk/ ResearchBriefing/Summary/SN05974\#fullreport (дата звернення: 10.12.2019).

13. Reduction in Sentence for a Guilty plea Definitive Guideline / URL: https://www.sentencingcouncil.org.uk/wp-content/ uploads/Reduction-in-Sentence-for-Guilty-Pleadefinitive-guideline-SC-Web.pdf (дата звернення: 10.12.2019).

The article examines and analyzes foreign experience of legal regulation of criminal consequences in case of conclusion of plea bargain. The example of the US and UK shows the peculiarities of sentencing in the case of a plea bargain in the Anglo-Saxon Legal System. A plea bargain is widespread in the US and the UK. It is established that the American model of conciliation procedures has become an ideological basis for the formation and dissemination of this method in criminal proceedings in other countries. The US criminal process provides for the possibility of concluding various Types of Criminal Pleas. The plea bargain is any agreement in a criminal case between the prosecutor and defendant whereby the defendant agrees to plead guilty or nolo contendere to a particular charge in return for some concession from the prosecutor. Their types are Sentence Bargaining and Charge bargaining. Sentence bargaining involves assurances of lighter or alternative sentences in return for a defendant's pleading guilty. Charge bargaining involves assurances, if the defendant accepts this type of plea bargain, then he pleads guilty to a crime that is less serious than what he was initially charged with. Another kind of agreement in the US criminal process is a cooperation agreement. Its content is to facilitate the suspect to investigate and prosecute the criminal activities of other non-accused persons in exchange for the mandatory mitigation of criminal liability. Under UK law, if a defendant pleads guilty to certain counts in the indictment, no other accusation is made and the liability is mitigated. The maximum level of sentence is one third of the maximum sentence for the crime committed, and the individual degree of mitigation depends on the stage of trial in the court in which such a statement was made. Where a guilty plea is indicated at the first stage of proceedings a reduction of one-third should be made. The first stage is the first hearing at which a plea or indication of plea is sought and recorded by the court. After the first stage of the proceedings the maximum level of reduction is one-quarter. The reduction should be decreased from one-quarter to a maximum of one-tenth on the first day of trial. The reduction should normally be decreased further, even to zero, if the guilty plea is entered during the course of the trial.

Key words: plea bargain, agreement, punishment, criminal conflict, sentence, criminal case. 